\title{
The assessment of external and operating indexes of LPG fueled engines
}

\author{
This paper presents the issues related to combustion engine fueling systems using gasoline and LPG. The results \\ of measurements carried out at the test stand enabled the analysis of the impact of alternative - LPG fueling on the \\ external indexes of the engine, i.e. maximum values of the torque and power. Knowing the values of such parameters, \\ with the maximum throttle opening (full-power characteristics), conclusions on engine dynamics have been drawn and \\ compared to the traditional fueling.
}

Key words: combustion engine, alternative fuels, tests

\section{Ocena wskaźników zewnętrznych i operacyjnych silników zasilanych LPG}

\begin{abstract}
W artykule przedstawiono problematykę układów zasilania silników spalinowych, wykorzystujacych benzynę i LPG. Wyniki pomiarów przeprowadzonych na hamowni podwoziowej pozwolity na przeanalizowanie wplywu rodzaju układu zasilania alternatywnego LPG na wskaźniki zewnętrzne silnika tj. wartości maksymalne momentu obrotowego i mocy. Dysponując wartościami tych parametrów w funkcji prędkości obrotowej przy maksymalnym otwarciu przepustnicy (charakterystyka zewnętrzna) wnioskowano o elastyczności silników, odnosząc je do zasilania tradycyjnego.
\end{abstract}

Słowa kluczowe: silnik spalinowy, paliwa alternatywne, badania

\section{Introduction}

The most commonly used alternative fuels at present are LPG, CNG, LNG, hydrogen and vegetable oil esters. In the case of spark ignition engines, the most extensively used are LPG fueling systems. The contemporary gasoline fueling systems are characterized with high level of complexity, which forces the manufacturers of alternative fueling systems to subordinate to complex OBD procedures. The additional fueling system installed, in addition to meeting the applicable standards concerning the exhaust emissions, must remain compliant with the OBD system, at the same time maintaining the external and operating indexes on the original system level.

The LPG fueling systems, throughout their evolution (very fast as compared to gasoline systems) evolved from the simplest - generation I and II LPG-air pre-mixing types, through indirect injection systems III, IV and V to the latest direct injection systems.

In the initial pre-mixing solutions, LPG was dosed under a similar principle to that in the carburetor (in this case: mixer), called vacuum-induced fuel delivery systems using additional restriction of fixed or varying flow capacity. This guaranteed the cooperation with the original carburetor or fuel injection system, even those with oxygen sensors operating in the closed-loop. The tolerance restriction of the mixture composition deviation forced the development of alternative systems with increased fuel dosage accuracy, therefore central and individual injectors were used operating with assumed gas pressure in the gaseous or liquid phase. The further changes in the structure of the original fueling systems, mainly the application of direct injection, impeded the process of adaptation to alternative fueling. At present tests are carried out on LPG fueling in the liquid

\section{Wprowadzenie}

W chwili obecnej najczęściej stosowanymi paliwami alternatywnymi są LPG, CNG, LNG, wodór, a także estry olejów roślinnych. W przypadku silników o ZI najszerzej wykorzystuje się układy zasilania gazem LPG. Współczesne benzynowe układy zasilania charakteryzują się dużym stopniem skomplikowania, co wymusza na producentach instalacji alternatywnych konieczność podporządkowania się skomplikowanym procedurom diagnostycznym OBD. Zamontowany dodatkowy układ zasilania musi, poza spełnieniem obowiązujących norm dotyczących emisji toksycznych składników spalin, pozostać w zgodności z układem ODB, przy utrzymaniu wskaźników zewnętrznych i operacyjnych na poziomie układu oryginalnego.

Układy zasilania LPG w toku swej ewolucji (w porównaniu z układami benzynowymi - bardzo szybkiej) ewaluowały od najprostszych - generacji I i II mieszalnikowych, poprzez układy wtrysku pośredniego generacji III, IV i V po najnowsze propozycje wtrysku bezpośredniego.

W początkowych rozwiązaniach mieszalnikowych, LPG dozowano na zasadzie podobnej do gaźnika (w tym przypadku mieszalnika), układami podciśnieniowymi wykorzystującymi dodatkowy dławik o stałej lub zmiennej przepustowości. Zapewniało to współpracę z silnikami o układach oryginalnych gaźnikowych, jak i wtryskowych, nawet $\mathrm{z}$ czujnikami tlenu, pracującymi w pętli sprzężenia zwrotnego. Zawężenie tolerancji odchyłki składu mieszaniny palnej, wymusiło opracowanie układów alternatywnych o zwiększonej dokładności dawkowania paliwa, stąd wykorzystanie wtryskiwaczy centralnych i indywidualnych pracujących przy założonym ciśnieniu gazu w fazie lotnej lub ciekłej. Dalsze zmiany w konstrukcji oryginalnych układów zasilania, głównie zastosowanie wtrysku bezpośredniego, 
phase through part of the original direct injection engine fueling system. The issue in this point is the fact that with direct injection in lean mixture operation mode, the injection takes place with closed intake valves, under high fuel pressure - the alternative indirect injection shall not ensure any restricted mixture regulation field in this point. In this case it will be necessary to use the original gasoline injectors, providing the appropriate fuel pressure.

One should expect this kind of alternative structures in the nearest future, because the modern gasoline structures in the time of downsizing shall be characterized with direct injection plus supercharging.

\section{Testing procedures}

During the design of the vehicle power transmission system, it is necessary to determine at the very beginning the values of power and torque in the function of engine speed. Assuming the maximum power value and corresponding engine speed as input data, with the use of the Leideman principle (with adequate selection of coefficients), we may obtain theoretical full-power characteristics that, in the course of calculations, should allow us to determine the traction characteristics of the vehicle and carry out strength calculations of the elements and subassemblies.

Therefore, an attempt was made to determine Leideman coefficients in relation to various configurations of LPG fueling system, comparing them to the original fueling systems.

The LPS 3000 MAHA test stand (Fig. 1) was used for the experiments.

The power measurement, determined directly through the total power on the wheels and tractive resistance power led to conclusions concerning the external indexes, power and torque.

The measurements were not repeated, each vehicle was tested once with LPG and once with gasoline fueling. At

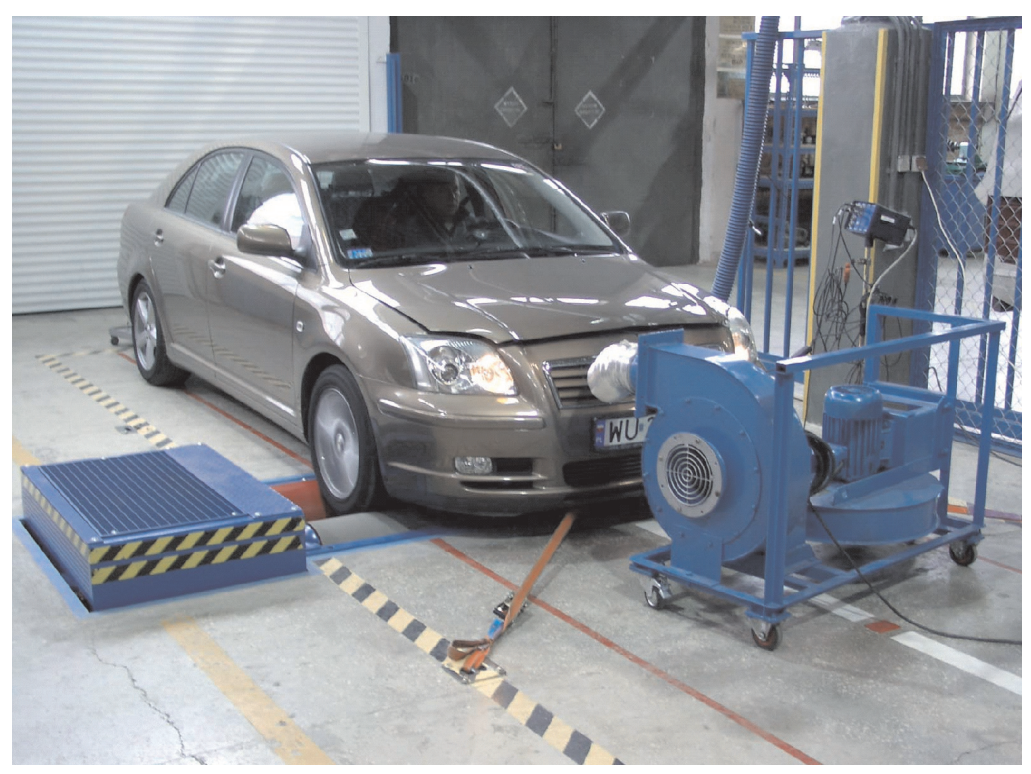

Fig. 1. Chassis dynamometer LPS 3000 MAHA

Rys. 1. Hamownia podwoziowa LPS 3000 MAHA utrudniło proces adaptacji do zasilania alternatywnego. Obecnie prowadzone są próby nad zasilaniem LPG w fazie ciekłej poprzez część oryginalnego układu zasilania silnika o bezpośrednim wtrysku. Problemem w tym miejscu jest fakt, iż przy wtrysku bezpośrednim, w chwili wtrysku w trybie pracy na mieszaninie ubogiej, wtrysk odbywa się przy zamkniętych zaworach dolotowych, pod wysokim ciśnieniem paliwa - alternatywny wtrysk pośredni w tym miejscu nie zapewni dodatkowo zawężonego pola regulacji składu mieszaniny. Koniecznym w tym przypadku jest wykorzystanie oryginalnych benzynowych wtryskiwaczy, zapewniając odpowiednie ciśnienie paliwa.

Można się spodziewać w najbliższym czasie takiego rodzaju konstrukcji alternatywnych, ponieważ współczesne konstrukcje benzynowe, w dobie downsizingu, będą charakteryzowały się bezpośrednim wtryskiem paliwa uzupełnionym o doładowanie.

\section{Procedury badawcze}

W toku projektowym układu napędowego pojazdu koniecznym jest określenie na wstępie wartości mocy i momentu obrotowego w funkcji prędkości obrotowej silnika (charakterystyka zewnętrzna). Przyjmując, jako dane wejściowe: wartość maksymalną mocy i odpowiadającą temu prędkość obrotową, przy wykorzystaniu zależności Leidemana (przy adekwatnym doborze współczynników) można otrzymać charakterystykę zewnętrzną teoretyczną, która w toku obliczeniowym pozwala na wyznaczenie charakterystyki trakcyjnej pojazdu i prowadzenie obliczeń wytrzymałościowych elementów i podzespołów.

Dlatego podjęto próbę wyznaczenia wartości współczynników Leidemana w odniesieniu do różnych konfiguracji układów zasilania $\mathrm{LPG}$, odnosząc je do oryginalnych układów zasilania.

W toku doświadczalnym wykorzystano hamownię podwoziową LPS 3000 MAHA (rys. 1).

Pomiar mocy, wyznaczany pośrednio poprzez sumę mocy na kołach i mocy oporów ruchu pojazdu pozwalał na wnioskowanie o wartościach wskaźników zewnętrznych, mocy i momentu obrotowego.

Zaniechano powtórzeń pomiarów, każdy pojazd badano jeden raz przy zasilaniu LPG i jeden przy benzynowym. W początkowej fazie poddano kolejnym badaniom jeden $\mathrm{z}$ pierwszych pojazdów wykazując, iż w kolejnych 5 próbach różnice nie były większe niż $1 \%$, czyli mieściły się w granicach tolerancji błędu podawanego przez producenta urządzenia (hamowni). Pojedynczy pomiar ograniczał również ewentualne uszkodzenia badanych pojazdów, gdyż były to pojazdy użyczane grzecznościowo, które niejednokrotnie charakteryzowały się przebiegiem powyżej 200 tys. km, a od daty produkcji $\mathrm{w}$ niektórych przypadkach minęło już ponad 10 lat.

Wykorzystując zgromadzone w ten sposób wyniki z hamowni podwoziowej LPS 3000 
the initial stage, further tests were carried out on one of the first vehicles proving that in 5 subsequent tests, the differences did not exceed $1 \%$, i.e. fitted within the limits of error tolerance stated by the equipment (test stand) manufacturer. Single measurement also reduced the possible damage to the tested vehicles, because these were made available courtesy of their owners (some of these vehicles had a mileage reading above 200.000 kilometers and in some cases the time since the date of manufacture exceeded 10 years).

Using the results obtained as above from the LPS 3000 MAHA test stand, conclusions were drawn on the differences in the values of external indexes of the engine with both types of fueling systems. Both the external and operating indexes of the engine, engine response, for example, are values determined from the measurements and their variability is conditioned by numerous structural-functional features. Therefore, the experimental procedure was supplemented with determination of the Leideman principle coefficients describing the engine power in the function of engine speed.

\section{Test objects}

Due to the vast size of the detailed technical data of the vehicles used for the comparison, the authors chose to present the quantitative specification of the particular groups herein.

The specific groups were represented by the following quantities of engines:

- gasoline -30 pcs.

- alternative LPG generation I - 7 pcs.,

- alternative LPG generation II - 12 pcs.,

- alternative LPG generation IV - 11 pcs.

Due to the low popularity of LPG fueling systems generation III and V, the latter were omitted in this analysis.

\section{Test results and their analysis}

The reference point in the comparative analysis consists of the maximum values of power and torque, although this does not always prove the right selection of the alternative fueling. The test stand results are presented in Table 1. Selected representatives of the particular groups were analyzed.

Fig. 2a presents the comparison of full-power characteristics of VW Golf 1.8GT engine, classically furnished with the SPI gasoline injection system and, alternatively, with the LPG fueling system generation I. The compliance of both power and torque values within the range $1800 \ldots 2400$ rpm is conspicuous here. In the higher ranges, increasing discrepancies occur, reaching in the maximum power point $3 \mathrm{~kW}$ difference (5.4\% compared to gasoline fueling). The initial compliance of values may be due to the fact that with the throttle valve fully open, within low engine speed range, resulting from high load, a slight sub-pressure occurs in the intake system $(-0,02 \mathrm{MPa}[5])$, causing the oscillation of the reducer-gas evaporator flow capacity within the maximum value limits.

The growing difference in the values of power and torque with higher engine speeds may be caused by inadequate ad-
MAHA, wnioskowano o różnicach w wartościach wskaźników zewnętrznych silnika przy obu rodzajach układów zasilania. Zarówno wskaźniki zewnętrzne silnika, jak i operacyjne, w postaci np. elastyczności są wartościami wyznaczonymi z pomiarów, a ich zmienność uwarunkowana jest wieloma cechami konstrukcyjno-funkcjonalnymi. Dlatego tok doświadczalny uzupełniono o wyznaczenie współczynników zależności Leidemana opisujących moc silnika w funkcji prędkości obrotowej.

\section{Obiekty badań}

Z uwagi na obszerność szczegółowych danych technicznych pojazdów biorących udział w porównaniu, zdecydowano się zaprezentować w artykule jedynie zestawienie liczebności poszczególnych grup.

Poszczególne grupy reprezentowały silniki w liczbie: - benzynowe - 30 szt.

- alternatywne LPG I generacji - 7 szt.,

- alternatywne LPG II generacji - 12 szt., - alternatywne LPG IV generacji - 11 szt.

Z uwagi na małą popularność układów LPG III i V generacji pominięto je $\mathrm{W}$ analizie.

\section{Wyniki badań $\mathrm{i}$ ich analiza}

W analizie porównawczej operuje się wartościami maksymalnymi mocy i momentu jako punktem odniesienia, choć nie zawsze świadczy to o poprawnym doborze zasilania alternatywnego. Wyniki badań hamownianych przedstawiono w tabeli 1 . Analizie poddano wybranych reprezentantów poszczególnych grup.

Na rys. 2a przedstawiono porównanie charakterystyk zewnętrznych silnika pojazdu VW Golf 1.8GT, klasycznie wyposażonego w centralny układ wtryskowy benzyny SPI i alternatywnie w układ zasilania LPG generacji I. Widoczna jest zgodność wartości zarówno mocy jak i momentu obrotowego w zakresie $1800 \ldots 2400$ [obr/min]. W wyższym występują narastające rozbieżności, osiągające w punkcie mocy maksymalnej $3 \mathrm{~kW}$ różnicy $(5,4 \% \mathrm{w}$ stosunku do zasilania benzynowego). Początkowa zgodność wartości może wynikać z faktu, iż przy pełnym otwarciu przepustnicy, w zakresie niskiej prędkości obrotowej, będącej wynikiem dużego obciążenia, występuje niewielkie podciśnienie w układzie dolotowym (-0,02MPa [5]), przez co przepustowość reduktora-parownika gazu oscyluje w granicach wartości maksymalnej.

Narastająca różnica w wartościach mocy i momentu obrotowego przy wyższych prędkościach obrotowych może wynikać z faktu nieodpowiedniej regulacji składu mieszaniny palnej, co w przypadku układów I generacji dokonywane jest okresowo manualnie. Należy pamiętać jednak, że reduktor-parownik ma ograniczoną przepustowość i zdolność rozprężania gazu ciekłego, co bezpośrednio wpływa na wartości maksymalne mocy i momentu obrotowego. Dodatkowo gaz LPG zajmuje większą objętość, niż ma to miejsce w przypadku benzyny, przez co generuje się zjawisko braku tlenu niezbędnego w procesie spalania, znajdujące bezpośrednie odzwierciedlenie w spadku wyżej wymienionych wskaźników zewnętrznych. 
a)

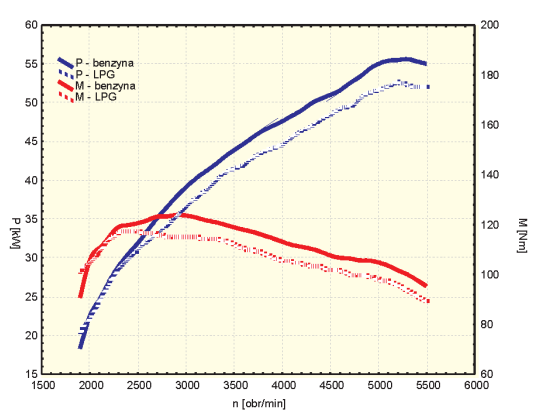

c)

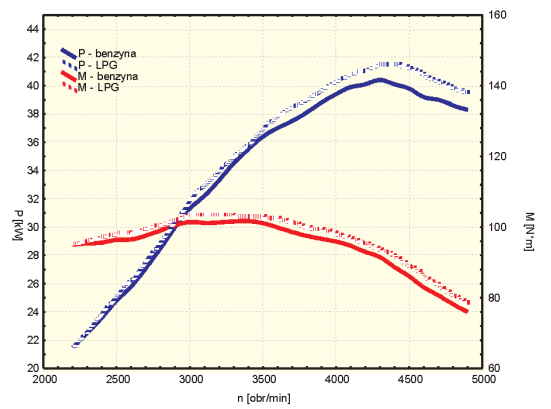

b)

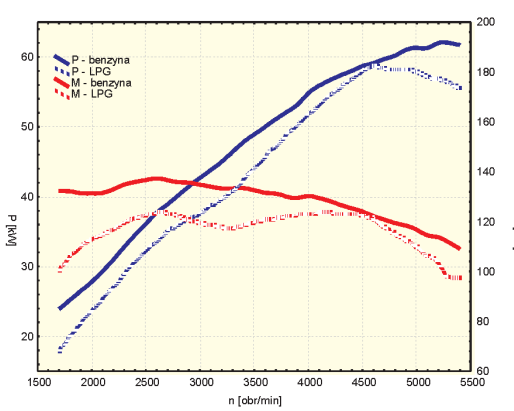

Fig. 2. Comparative full-power characteristics of engines: a - VW Golf 1.8 GT (SPI LPG generation I); b - Mazda 6261.8 (MPI - LPG generation II), c - Seat Ibiza 1.4 (MPI - LPG generation IV)

Rys. 2. Porównawcze charakterystyki zewnętrzne silnika: $a-V W$ Golf 1.8GT (SPI - LPG I generacji); $b$ - Mazda 6261.8 (MPI

- LPG II generacji), c - Seat Ibiza 1.4 (MPI - LPG generacji IV) justment of the fuel mixture components, which in the case of generation I system is made manually - on a periodical basis. One should remember, however, that the reducer-gas evaporator has a limited flow capacity and ability to compress liquid gas. In addition, LPG occupies larger volume than gasoline, which causes the lack of oxygen necessary in the combustion process, in consequence reflected in the decrease of the external indexes mentioned above.

The engine of Mazda 6261.8 was classically furnished with MPI, while LPG generation II was applied as the alternative fueling system. In generation II system there is a feedback between the electrically controlled flow capacity restriction, responsible for the composition of the fuel-air mixture and the oxygen sensor measuring the oxygen volume in the exhaust. In the case of this particular engine (Fig. 2b) the decrease of both power and torque is conspicuous, with the maximum value difference of $5.2 \mathrm{~kW}(8.4 \%)$ compared to the gasoline fueling. The approximation of the values obtained with two fueling systems in the point corresponding to $4600 \mathrm{rpm}$ is visible. The equalization of the power and torque in this point was most probably caused by appropriate adaptation of the mixture composition or even its temporary enrichment, because, as hinted in paper [9] the engine generates maximum torque within the range $\lambda=0.95$.

Another vehicle analyzed was Seat Ibiza 1.4. Its engine with multi-point sequential injection system of gasoline was alternatively furnished with sequential gas injection system. The correlation (Fig. 2c) between the power and torque values for both fueling systems is visible, due to the fact of close cooperation of the LPG injector control system and the electronic gasoline injection module. The alternative LPG fueling system as shown in the drawing (Fig. 2c) takes the lead over the classic gasoline system. The difference in this case is $1.1 \mathrm{~kW}(2,7 \%)$ compared to the maximum power with
Silnik pojazdu Mazda 6261.8 klasycznie wyposażony w wielopunktowy układ wtryskowy benzyny MPI, natomiast jako alternatywny układ zasilania zastosowano II generację LPG. W układzie II generacji występuje sprzężenie zwrotne pomiędzy dławikiem z elektrycznie sterowaną przepustowością, odpowiedzialnym za skład mieszaniny paliwowo-powietrznej, a sondą lambda mierzącą ilość tlenu w spalinach. W przypadku tego silnika (rys. 2b) widoczne jest zmniejszenie wartości zarówno mocy jak i momentu obrotowego, $\mathrm{z}$ różnicą wartości maksymalnej mocy wynoszącą $5,2 \mathrm{~kW}(8,4 \%)$ względem zasilania benzynowego. Widoczne jest zbliżenie wartości otrzymanych przy dwóch układach zasilania w punkcie odpowiadającym 4600 obr/min. Wyrównanie mocy i momentu obrotowego w tym miejscu spowodowane było najprawdopodobniej właściwym dostosowanie składu mieszaniny, a nawet jej chwilowym wzbogaceniem, ponieważ jak sygnalizowano $\mathrm{w}$ pracy [9] silnik generuje maksymalny moment obrotowy w obrębie $\lambda=0,95$.

Kolejnym $\mathrm{z}$ pojazdów poddanym $\mathrm{w}$ analizie jest Seat Ibiza 1.4. Jego silnik z wielopunktowym sekwencyjnym układem wtryskowym benzyny otrzymał zamiennie sekwencyjny układ wtryskowy gazu. Widoczna jest (rys. 2c) relacja pomiędzy wartościami mocy i momentu obrotowego przy obu układach zasilania, z uwagi na fakt ścisłej współpracy układu sterowania wtryskiwaczami LPG z elektronicznym modułem sterującym wtryskiem benzyny. Jak widać na (rys. 2c) alternatywny układ zasilania LPG przewyższa pod względem wartości maksymalnych mocy i momentu obrotowego klasyczny układ benzynowy. Różnica w tym przypadku wynosi 1,1 kW (2,7\%) w stosunku do mocy maksymalnej przy zasilaniu benzynowym. Tak dobre efekty uzyskano przy zastosowaniu dodatkowego urządzenia przetwarzającego sygnał z sondy lambda do sterowania dawką LPG. Z drugiej zaś strony, stwierdzono podwyższone stężenie węglowodorów w spalinach przy zasilaniu LPG przy niskiej prędkości obrotowej i dużym obciążeniu, w zakresie podwyższonych prędkości obrotowych (okolice mocy maksymalnej) wzrosła emisja tlenków azotu.

Elastyczność silnika spalinowego mówi o jego zdolności przystosowania do zmiennych obciążeń i prędkości obrotowych (rys. 3). Dla silników trakcyjnych jest to bardzo istotny wskaźnik określający możliwości eksploatacyjne. Liczbowym wyrazem elastyczności silnika jest współczynnik elastyczności (1).

Aby porównać zasilanie klasyczne z alternatywnym pod kątem mocy maksymalnej, maksymalnego momentu obrotowego i współczynnika elastyczności, posłużono się korelacją rang, która starała się odpowiedzieć na pytanie: 
gasoline fueling. The very good effects were obtained with the use of additional device converting the signal from the oxygen sensor controlling the LPG dose. On the other hand, increased concentration of hydrocarbons was observed in the exhaust with LPG fueling, low engine speed and high load, while in the range of increased engine speeds (ca. maximum) the emissions of nitrogen oxides grew.

The flexibility of the combustion engine tells about its capacity to adapt to the varying loads and engine speeds (Fig. $3)$. For traction engines this is a very significant index determining the operating potential. The numerical expression of engine dynamics is the dynamics coefficient (1).

$$
\mathrm{E}=\frac{\mathrm{M}_{\max }}{\mathrm{M}_{\mathrm{N} \max }} \cdot \frac{\mathrm{n}_{\mathrm{N}}}{\mathrm{n}_{\mathrm{M} \max }}
$$

To compare classic and alternative fueling in terms of maximum power, torque and dynamics coefficient, the authors used the correlation of ranks, which was an attempt to answer the question whether alternative fueling affects the external and operating indexes of a combustion engine. This means that the assumed average difference should equal zero, in order to check this hypothesis (instead of testing randomly selected representatives of specific groups, all the vehicles of all the groups were tested). Therefore, if we do not test the whole populations, then we shall read the boundary value of $\mathrm{t}$-Student test for $\mathrm{n}-1$ degrees of freedom, with significance level 0.05 .

Comparing measuring results of LPG generation I gasoline, with 7 cars, we may observe that the maximum power decreases by ca. $7.6 \%$ with alternative fueling, the maximum torque by $10.2 \%$, while the engine dynamics increases by $0.4 \%$.

In the case of LPG generation II, the engine power decreases by ca. $5.5 \%$, the maximum torque by $8 \%$, while the engine dynamics remains on almost unchanged level $(0.04 \%$ difference) with 32 cars.

Comparing LPG generation IV to gasoline systems - the maximum power difference is $3.9 \%$, maximum torque $3.5 \%$, and engine dynamics $0.1 \%$ with 16 cars against LPG fueling.

Comparing the average differences (Table 1) we can see that an LPG fueled engine will be characterized with lower maximum power by $5.71 \%$, lower torque by $7.27 \%$ and higher dynamics by $0.08 \%$.

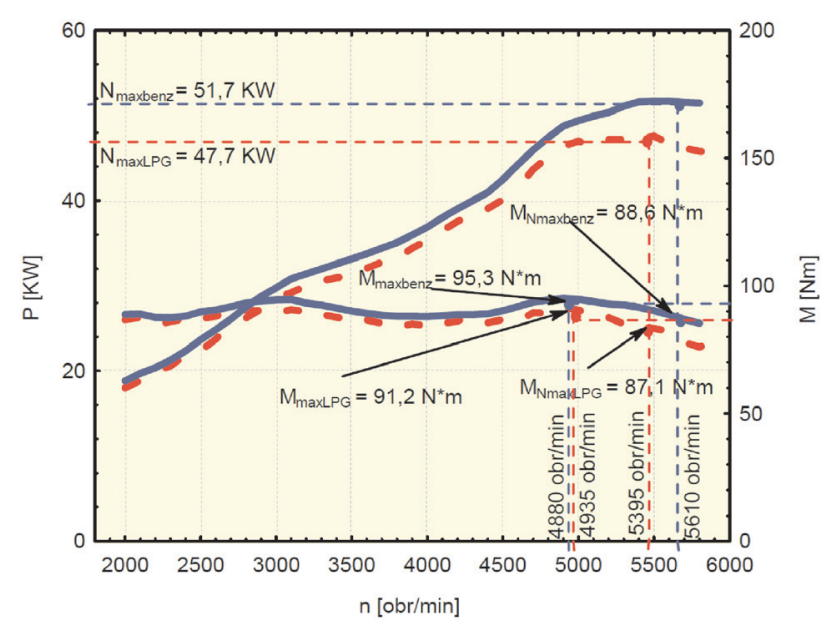

Fig. 3. Comparative full-power characteristics of Honda Civic 1.4 engine with classic MPI (-) and alternative LPG generation II fueling systems (- - )

Rys. 3. Porównawcze charakterystyki zewnętrzne silnika pojazdu Honda Civic 1.4 przy uktadzie zasilania klasycznym MPI (-) i alternatywnym $L P G$ generacji II (- - -)

czy zasilanie alternatywne wpływa na wskaźniki zewnętrzne i operacyjne silnika spalinowego? Oznacza to, że w celu sprawdzenia tej hipotezy (nie poddając badaniom losowo wybranych reprezentantów poszczególnych grup, a wszystkie pojazdy w poszczególnych grupach) przyjmujemy, że średnia różnic powinna być równa zeru. Wobec tego, jeżeli nie badamy całkowitych populacji, to wartość graniczną testu t-Studenta odczytujemy dla n-1 stopni swobody, przy poziomie istotności 0,05 .

Zestawiając wyniki pomiarów LPG I generacji - benzyna, przy 7 samochodach można stwierdzić, iż przy zasilaniu alternatywnym moc maksymalna obniża się o ok. 7,6\%, maksymalny moment obrotowy o $10,2 \%$, natomiast elastyczność silnika wzrasta o $0,4 \%$.

W przypadku alternatywnych układów zasilania LPG II generacji, moc silnika spada o ok. 5,5\%, maksymalny moment obrotowy o $8 \%$, elastyczność silnika pozostaje prawie na niezmiennym poziomie $(0,04 \%$ różnicy) przy 32 samochodach.

Porównując układy LPG IV generacji z benzynowymi - różnica mocy maksymalnej wynosi 3,9\%, maksymalnego momentu obrotowego $3,5 \%$, a elastyczności $0,1 \%$ przy 16

Table 1. Specification of measuring results - average values

Tabela 1. Zestawienie wyników pomiarów-wartości średnie

\begin{tabular}{|l|c|c|c|}
\hline Fueling/zasilanie & \multicolumn{3}{|c|}{ Average difference [\%] from tests/średnia różnica [\%] z prób } \\
\hline $\begin{array}{l}\text { Gasoline - LPG/benzyna } \\
-L P G\end{array}$ & $\begin{array}{l}\text { Maximum power/ } \\
\text { moc maksymalna }\end{array}$ & $\begin{array}{c}\text { Maximum torque/ } \\
\text { maksymalny moment obr. }\end{array}$ & $\begin{array}{c}\text { Dynamics/ } \\
\text { elastyczność }\end{array}$ \\
\hline $\begin{array}{l}\text { Generation I (7 cars)/I gene- } \\
\text { racja (7 samochodów) }\end{array}$ & 7.63 & 10.27 & -0.39 \\
\hline $\begin{array}{l}\text { Generation II (32 cars)/II } \\
\text { generacja (32 samochody) }\end{array}$ & 5.56 & 8.02 & 0.05 \\
\hline $\begin{array}{l}\text { Generation IV (16 cars)/IV } \\
\text { generacja (16 samochodów) }\end{array}$ & 3.95 & 3.53 & 0.11 \\
\hline \begin{tabular}{l} 
Average/średnia \\
\hline
\end{tabular} & 5.71 & 7.27 & -0.08 \\
\hline
\end{tabular}


Table 2. Comparison of calculative statistics value $t$ to the critical

Tabela 2. Zestawienie wartości statystyki tobliczeniowej z krytyczna

\begin{tabular}{|l|c|c|c|}
\hline \multirow{2}{*}{ Indexes/wskaźniki } & \multicolumn{3}{|c|}{ Comparative groups (pairs)/grupy porównawcze (pary) } \\
\cline { 2 - 4 } & $\begin{array}{c}\text { gasoline - LPG generation I/ } \\
\text { benzyna - I generacja LPG }\end{array}$ & $\begin{array}{c}\text { gasoline - LPG generation II/ } \\
\text { benzyna - II generacja LPG }\end{array}$ & $\begin{array}{c}\text { gasoline - LPG generation IV/ } \\
\text { benzyna - IV generacja LPG }\end{array}$ \\
\hline $\begin{array}{l}\text { Maximum power/ } \\
\text { moc maksymalna }\end{array}$ & 2.78073 & 5.74185 & 3.85205 \\
\hline $\begin{array}{l}\text { Maximum torque/ } \\
\text { maks. moment obr }\end{array}$ & 5.07721 & 7.33066 & 3.10374 \\
\hline $\begin{array}{l}\text { Engine dynamics/ } \\
\text { elastyczność silnika }\end{array}$ & 2.22428 & 0.46349 & 1.26944 \\
\hline $\mathrm{t}_{\mathrm{gr}}(\mathrm{n} ; \alpha=0.05)$ & 2.447 & 2.042 & 2.120 \\
\hline
\end{tabular}

Determining critical value $\mathrm{t}$ [3] for the specific groups and comparing them with calculating values $t$ (Table 2 ) it is conspicuous that only in the case of engine dynamics there are no foundations for rejecting the zero hypothesis, whereas in the other cases we may state that alternative fueling significantly affects the combustion engine external indexes. Thorough statistical analysis was included in [7].

Regardless of the LPG generation, power and torque will mostly reach lower values in this case of fueling, only the engine dynamics in some cases is higher for gas fueling, while LPG systems generation I have decisive impact here, which was hinted already in [7].

The further analysis was to determine Leideman function coefficients (2). After determining the values of A, B and C coefficients and the theoretical values of torque were also calculated (3) having the power values dependent on the engine speed available.

$$
\begin{gathered}
\mathrm{N}=\mathrm{N}_{\max }\left[\mathrm{A} \cdot \frac{\mathrm{n}}{\mathrm{n}_{\mathrm{N}}}+\mathrm{B} \cdot\left(\frac{\mathrm{n}}{\mathrm{n}_{\mathrm{N}}}\right)^{2}-\mathrm{C}\left(\frac{\mathrm{n}}{\mathrm{n}_{\mathrm{N}}}\right)^{3}\right] \mathrm{kW} \\
\mathrm{M}=\mathrm{M}_{\mathrm{N}}\left[\mathrm{A}+\mathrm{B} \frac{\mathrm{n}}{\mathrm{n}_{\mathrm{N}}}-\mathrm{C}\left(\frac{\mathrm{n}}{\mathrm{n}_{\mathrm{N}}}\right)^{3}\right] \mathrm{N} \cdot \mathrm{m}
\end{gathered}
$$

Coefficients A, B and C are permanent for the specific engine, in [2] their values were presented, for carburetor fueling cases of spark ignition and injection to the pre-chamber and direct injection of spark ignition engines, but no reference to the alternative LPG fueling was given.

To determine the values of $\mathrm{A}, \mathrm{B}$ and $\mathrm{C}$ coefficients, Matlab environment with Guide addition $[1,4,8]$ was used. For the numerical identification (Fig. 4), the non-linear method was applied, minimizing the FPE1 index (4). The minimization was carried out by the numerically non-gradient Nelder - Mead method.

$$
\mathrm{FPE} 1=\frac{\mathrm{m}+1}{\mathrm{~m}(\mathrm{~m}-1)} \sum_{\mathrm{i}=1}^{\mathrm{m}}\left(\mathrm{N}_{\mathrm{d}}-\mathrm{N}_{\mathrm{m}}\right)^{2}
$$

samochodach, na niekorzyść zasilania LPG.

Zestawiając średnie różnic (tab. 1) można zauważyć, że silnik zasilany LPG będzie charakteryzował się mniejszą mocą maksymalną o 5,71\%, momentem obrotowym mniejszym o 7,27\% i elastycznością większą o $0,08 \%$.

Określając z tabeli krytyczną wartość t [3] dla poszczególnych grup i zestawiając je z wartościami t obliczeniowymi (tab. 2) widać, iż jedynie w przypadku elastyczności silnika, nie ma podstaw do odrzucenia hipotezy zerowej, w pozostałych natomiast można stwierdzić, iż zasilanie alternatywne istotnie wpływa na wskaźniki zewnętrze silnika spalinowego. Wnikliwą analizę statystyczną zawarto w [7].

Niezależnie od generacji LPG moc i moment obrotowy będą osiągały przeważnie wartości mniejsze w tym przypadku zasilania, jedynie elastyczność silnika w pewnej części przypadków jest większa dla zasilania gazowego, decydujący wpływ mają tu instalacje gazowe I generacji, co sygnalizowano już w [7].

Dalsza analiza miała na celu wyznaczenie współczynników funkcji Leidemana (2). Po wyznaczeniu wartości współczynników A, B i C obliczano również teoretyczne wartości momentu obrotowego wg zależności (3) mając do dyspozycji wartości mocy zależne od prędkości obrotowej.

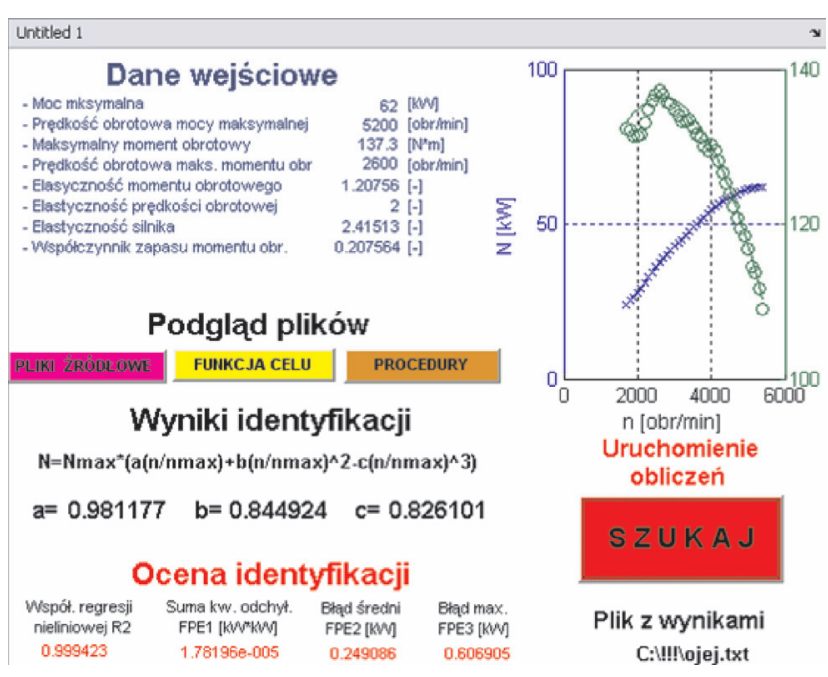

Fig. 4. Dialog box made in the Matlab-Simulink package with a Guide add-on

Rys. 4. Okno dialogowe stworzone w pakiecie Matlab-Simulink dodatek Guide 
The qualitative assessment of adaptation of power, experimental $\mathrm{N}_{\mathrm{d}}$ and model $\mathrm{N}_{\mathrm{m}}$ values was made through the non-linear regression coefficient adjusted by the degrees of freedom (5).

$$
\mathrm{R}^{2}=1-\frac{\mathrm{m}-1}{\mathrm{~m}-1} \cdot \frac{\sum_{\mathrm{i}=1}^{\mathrm{m}}\left(\mathrm{N}_{\mathrm{d}}-\mathrm{N}_{\mathrm{m}}\right)}{\sum_{\mathrm{i}=1}^{\mathrm{m}}\left(\mathrm{N}_{\mathrm{d}}-\overline{\mathrm{N}_{\mathrm{m}}}\right)^{2}}
$$

Additionally, the FPE2 coefficient was determined, representing average error (6).

$$
\mathrm{FPE} 2=\frac{1}{\mathrm{~m}} \sum_{\mathrm{i}=1}^{\mathrm{m}}\left|\mathrm{N}_{\mathrm{d}}-\mathrm{N}_{\mathrm{m}}\right|
$$

And maximum error value FPE3 (7).

$$
\mathrm{FPE} 3=\operatorname{MAX}\left|\mathrm{N}_{\mathrm{d}}-\mathrm{N}_{\mathrm{m}}\right|
$$

Paper [6] contains the statistical analysis of the results presented where the normal status of the distributions was tested and the significance of the determined averages was verified as well as the probability that the average should occur outside the critical area, indicating the reliability range of such an occurrence.

The analysis presented in paper [6] suggests that the distribution of values in some cases significantly diverges from normal, which can be caused by too low a number of tests (LPG generation I), and varied technical condition of the vehicles (engines) tested.

Assessing quantitatively the parameter identification process, it was observed that the FPE2 index fitted within $1 \mathrm{~kW}$, while the non-linear regression coefficient $\mathrm{R}^{2}$ oscillated within the 0.99 limits.

\section{Summary}

The tests carried out showed a significant impact of LPG fueling on reducing the external index values of spark ignition combustion engines. The average decrease of maximum power is by $5.71 \%$ and of torque by $7.27 \%$. Only the dynamics is higher by $0.08 \%$, which is not certain, with
Współczynniki A, B i C są stale dla danego silnika, w [2] zaprezentowano ich wartości, dla przypadków zasilania gaźnikowego silników ZI i wtryskowego do komory wstępnej i bezpośredniego silników o ZS, nie podano jednak odniesienia do zasilania alternatywnego LPG.

Do wyznaczenia wartości współczynników A, B i C wykorzystano środowisko Matlab z dodatkiem Guide [1, 4, 8]. W toku identyfikacji numerycznej (rys. 4) posłużono się metodą regresji nieliniowej, minimalizując wskaźnik FPE1 (4). Minimalizację przeprowadzano numerycznie bezgradientową metodą sympleksu Neldera - Meada.

Oceny jakościowej dopasowania wartości mocy, doświadczalnej $\mathrm{N}_{\mathrm{d}}$ i modelowej $\mathrm{N}_{\mathrm{m}}$ dokonywano na podstawie wartości współczynnika regresji nieliniowej skorygowanego na stopnie swobody (5).

Dodatkowo wyznaczano wskaźnik FPE2 reprezentujący błąd średni (6).

Jak też maksymalną wartość błędu FPE3 (7).

W opracowaniu [6] znajduje się analiza statystyczna zaprezentowanych wyników, gdzie testowano normalność rozkładów, jak też weryfikowano istotność wyznaczonych wartości średnich i prawdopodobieństwo, przy jakim średnia znajdzie się poza obszarem krytycznym ze wskazaniem przedziału ufności, przy jakim to wystąpi.

Z analizy przedstawionej w pracy [6] wynika, iż rozkład wartości w niektórych przypadkach znacznie odbiega od normalnego, co może być spowodowane zbyt małą liczebnością prób (LPG I gen.), jak również zróżnicowanym stanem technicznym pojazdów (silników) biorących udział w badaniach.

Oceniając jakościowo proces identyfikacji parametrów stwierdzono, że wskaźnik FPE2 zawierał się poniżej $1 \mathrm{~kW}$. $\mathrm{Z}$ kolei współczynnik regresji nieliniowej $\mathrm{R}^{2}$ oscylował w granicach 0,99 .

\section{Podsumowanie}

Przeprowadzone badania wykazały istotny wpływ zasilania LPG na zmniejszenie wartości wskaźników zewnętrznych silników spalinowych o zapłonie iskrowym. Moc maksymalna spada średnio o 5,71\%, moment obrotowy o 7,27\%. Jedynie elastyczność jest większa o $0,08 \%$, co do której nie ma pewności przy poziomie istotności 0,05 . Oczywistym jest, że pomiary, które zostały zaszeregowane do poszczególnych grup, można jedynie uznać za ich repre-

Table 3. Leideman coefficient values obtained through numerical identification

Tabela 3. Wartości współczynników Leidemana otrzymane drogą identyfikacji numerycznej

\begin{tabular}{|l|c|c|c|c|c|}
\hline \multirow{2}{*}{$\begin{array}{l}\text { Fueling system type/rodzaj } \\
\text { układu zasilania }\end{array}$} & \multicolumn{2}{|c|}{ Averages from tests/wartości średnie z prób } & \multicolumn{3}{|c|}{ Standard deviation/odchylenie standardowe } \\
\cline { 2 - 6 } & $\mathrm{A}$ & $\mathrm{B}$ & $\mathrm{C}$ & $\mathrm{A}$ & $\mathrm{B}$ \\
\hline $\begin{array}{l}\text { Gasoline fueling/ } \\
\text { zasilanie benzynowe }\end{array}$ & 0.52805 & 1.66203 & 1.19010 & 0.34592 & 0.79432 \\
\hline $\begin{array}{l}\text { LPG generation I/ } \\
\text { LPG I generacji }\end{array}$ & 0.72078 & 1.32820 & 1.04899 & 0.38034 & 0.47011 \\
\hline $\begin{array}{l}\text { LPG generation II/ } \\
\text { LPG II generacji }\end{array}$ & 0.55145 & 1.57321 & 1.12466 & 0.20488 & 0.53275 \\
\hline $\begin{array}{l}\text { LPG generation IV/ } \\
\text { LPG IV generacji }\end{array}$ & 0.55145 & 1.57321 & 1.12466 & 0.20488 & 0.40766 \\
\hline
\end{tabular}


the significance level 0.05 . It is obvious that the measurements that were classified within the particular groups can only be regarded as their representatives and allow to make conclusions only on the differences throughout the whole population.

The attempt to determine the Leideman coefficient values (Table 3) in relation to LPG fueling gave no statistically satisfactory results, either. The divergences between the results of the particular tests are due to the significant diversification and structural complexity of various engine makes as well as the algorithms controlling them. We may create „template" theoretical characteristics of combustion engines with various fueling that enable us to draw conclusions on their usability in the engineering calculations. zentantów i pozwalają wnioskować jedynie o różnicach w całej populacji.

Próba wyznaczenia wartości współczynników Leidemana (tab. 3) w odniesieniu do zasilania LPG również nie dała zadowalających wyników w ujęciu statystycznym. Rozbieżności pomiędzy wynikami z poszczególnych prób wynikają ze znacznego zróżnicowania i skomplikowania budowy silników różnych marek, jak i algorytmów nimi sterujących. Można na podstawie wyliczonych wartości współczynników A, B i C stworzyć ,,wzorcowe” charakterystyki teoretyczne silników spalinowych o różnym zasilaniu, które pozwalają wnioskować o ich przydatności w obliczeniach inżynierskich.

\section{Bibliography/Literatura}

[1] Luszniewicz A., Słaby T.: Statystyka z pakietem komputerowym STATISTICATM PL, Wyd. C.H.Beck, Warszawa, 2001.

[2] Mysłowski J.: Obliczenia cieplne silników samochodowych: (poradnik do ćwiczeń) Wyd. Politechniki Szczecińskiej, Szczecin, 1988.

[3] Puchalski T.: Statystyka - Wykład podstawowych zagadnień, PWN, Warszawa, 1977.

[4] Regel W.: Statystyka matematyczna w programie MATLAB, Wyd. MIKOM, Warszawa, 2003.

[5] Szpica D., Czaban J.: Badania porównawcze pojazdów wyposażonych w silniki z klasycznymi i alternatywnymi układami zasilania na hamowni podwoziowej, Przegląd Mechaniczny, nr 6, s.15-20, 2005.

[6] Szpica D., Czaban J.: Zależność Leidemana a współczesne konstrukcje silników spalinowych, Przegląd Mechaniczny, nr 6, s. 24-29, 2010.

[7] Szpica D., Czaban J.: Porównanie klasycznych i alternatywnych układów zasilania silników na podstawie charakterystyk zewnętrznych, Przegląd Mechaniczny, nr 7/8, s. 26-31, 2009;

[8] Zalewski A., Cegiełka A.: Matlab - obliczenia numeryczne i ich zastosowanie, Wyd. PWN, Warszawa, 2000.

[9] Zimmerman A. A. et al.: Improved fuel distribution - A new role for gasoline additives Esso Research and Eng. Co, SAE Tr. 1972.

\section{List of symbols/Wykaz oznaczeń}

A, B, C-Leideman coefficients/współczynniki Leidemana

1 number of significant model coefficients/liczba istotnych wspótczynników modelu

m number of identified curve points/liczba punktów identyfikowanej krzywej

$\mathrm{M}$ engine torque $[\mathrm{N} \cdot \mathrm{m}] /$ moment obrotowy silnika $[N \cdot \mathrm{m}]$

$\mathrm{M}_{\max }$ maximum engine torque $[\mathrm{N} \cdot \mathrm{m}] /$ maksymalny moment obrotowy silnika $[N \cdot m]$

$\mathrm{M}_{\mathrm{Nmax}}$ torque corresponding to the rated power $[\mathrm{N} \cdot \mathrm{m}] /$ moment obrotowy odpowiadajacy mocy znamionowej $[N \cdot \mathrm{m}]$

$\mathrm{N}$ engine power $[\mathrm{kW}] /$ moc silnika $[\mathrm{kW}]$

$\mathrm{n}$ engine speed [rpm]/prędkość obrotowa [obr/min]

$\mathrm{N}_{\mathrm{d}}$ experimental power values $[\mathrm{kW}] /$ doświadczalne wartości mocy [kW]

$\mathrm{N}_{\mathrm{m}}$ model power values $[\mathrm{kW}] /$ modelowe wartości mocy $[\mathrm{kW}]$

$\mathrm{n}_{\mathrm{Mmax}}$ engine speed at maximum torque [rpm]/prędkość obrotowa maksymalnego momentu obrotowego [obr/min]

$\mathrm{n}_{\mathrm{N}}$ rated engine speed [rpm]/znamionowa prędkość obrotowa [obr/min]
Mr. Dariusz Szpica, DEng. - doctor in the Faculty of Mechanical Engineering at Białystok University of Technology.

Dr inż. Dariusz Szpica - adiunkt na Wydziale Mechanicznym Politechniki Białostockiej.

e-mail:dszpica@pb.bialystok.pl

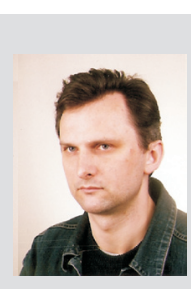

Mr. Jarosław Czaban, DEng. - doctor in the Department of Machine Design and Operation at Białystok University of Technology.

Dr inż. Jarosław Czaban - adiunkt na Wydziale Mechanicznym Politechniki Białostockiej.

e-mail:jczaban@pb.bialystok.pl 